\title{
Prototype Design of Bukaloka Mobile Marketplace Application Using Five Planes Method
}

\author{
I Gusti Ngurah Indra Mahathanaya ${ }^{\mathrm{a} 1}$, Ni Kadek Ayu Wirdiani ${ }^{\mathrm{a} 2}$, Ni Kadek Dwi Rusjayanthi ${ }^{\mathrm{a} 3}$ \\ ${ }^{\text {a }}$ Program Studi Teknologi Informasi, Fakultas Teknik, Universitas Udayana \\ Bukit Jimbaran, Bali, Indonesia, telp. (0361) 701806 \\ e-mail: ${ }^{1}$ indramahathanaya@gmail.com, ${ }^{2}$ ayu wirdi@yahoo.com, ${ }^{3}$ dwi.rusjayanthi@gmail.com
}

\begin{abstract}
Abstrak
Bukaloka merupakan sebuah aplikasi asal Bali yang bergerak dalam bidang pariwisata mengenai e-voucher. Layanan e-voucher yang disediakan oleh Bukaloka membuat pengguna dengan mudah membeli dan menukarkan e-voucher tanpa perlu mencetak voucher. Aplikasi Marketplace Bukaloka belum tersedia untuk platform mobile, sehingga tidak memudahkan akses pengguna mobile. Perancangan User Experience diperlukan untuk memudahkan pengembangan aplikasi, juga penerimaan pengguna. Metode perancangan User Experience yang digunakan adalah Five Planes sehingga pondasi dasar yang menghasilkan prototipe dengan tingkat high fidelity dapat diuji menyerupai aplikasi akhir. Pengujian prototipe menggunakan Metode User Acceptance Test dengan Likert's Summated Rating. Hasil yang didapat adalah prototipe Marketplace memperoleh skor 815 yang termasuk dalam rentang kategori sangat bagus.
\end{abstract}

Kata kunci: Aplikasi Bukaloka, Perancangan Prototipe, User Experience, Five Planes, User Acceptance Test.

\begin{abstract}
Bukaloka is an application from Bali which is engaged in tourism regarding e-vouchers. The e-voucher service provided by Bukaloka allows users to easily buy and exchange evouchers without the need to print vouchers. The Bukaloka Marketplace application is not yet available for the mobile platform, so it does not facilitate access for mobile users. User Experience design is needed to facilitate application development, as well as user acceptance. The User Experience design method used is Five Planes so that the basic foundation that produces a prototype with a high fidelity level can be tested to resemble the final application. Testing the prototype using the User Acceptance Test Method with a Likert's Summated Rating. The result is that the Marketplace prototype gets a score of 815 which falls into the very good category range.
\end{abstract}

Keywords : Bukaloka Application, Prototype Design, User Experience, Five Planes, User Acceptance Test.

\section{Introduction}

Tourism is an important sector in many countries. Tourism has experienced continuous growth and diversification to become one of the largest and fastest growing economic sectors in the world over the last few decades [1]. More and more tourist destinations have been opened and invested in tourism development, making modern tourism a key driver of socio-economic progress [2]. Tourism in developing countries is an important source of income and the number one export category, creates many jobs and is an opportunity for development in a country [3]. Designing a User Experience prototype is one of the first steps that can be taken in the application development process [4]. One method in designing a prototype is the Five Planes Method [5]. The Five Planes method has been applied to an application design case study for stroke patients. The level of application usability seen from a perception and an ergonomic point of view shows that the user satisfaction index is in a satisfactory range with a satisfaction percentage of $81.4 \%$, so it can be said that the system works with satisfactory results for users [6]. The Five Planes method is also used for designing a tour package Marketplace application. Respondents think the prototype is easy to use in the booking and payment stages of tour packages with an error rate of at least $12.5 \%$ [7]. An example of a company that requires 
designing an application prototype is Bukaloka. Bukaloka does not yet have a mobile-based application, so Bukaloka has not been able to reach users who want to access the Bukaloka Marketplace through the mobile application [8]. The design of the Bukaloka Mobile Marketplace Application prototype needs to be done to simplify the application development process. The design of the Bukaloka Mobile Marketplace Application prototype was carried out using the Five Planes Method. Tests were carried out on the results of designing a prototype for the Bukaloka Mobile Marketplace Application to determine the feasibility of the prototype, so that Bukaloka could apply the prototype for application development [9]. Testing of the feasibility of the prototype was carried out using the User Acceptance Method with Likert's Summated Rating [10].

\section{Research Method}

The discussion of the research methodology is described to make it easier to understand the stages of research through the research flow and the basis for designing prototypes and testing used in research.

\subsection{Alur Penelitian}

The research flow is the stage in conducting research. The stages in the research began with running the Five Planes Prototype Design Method. Prototypes that have reached the final stage of the Five Planes are evaluated using the User Acceptance Test Method with a Likert's Summated Rating [11].

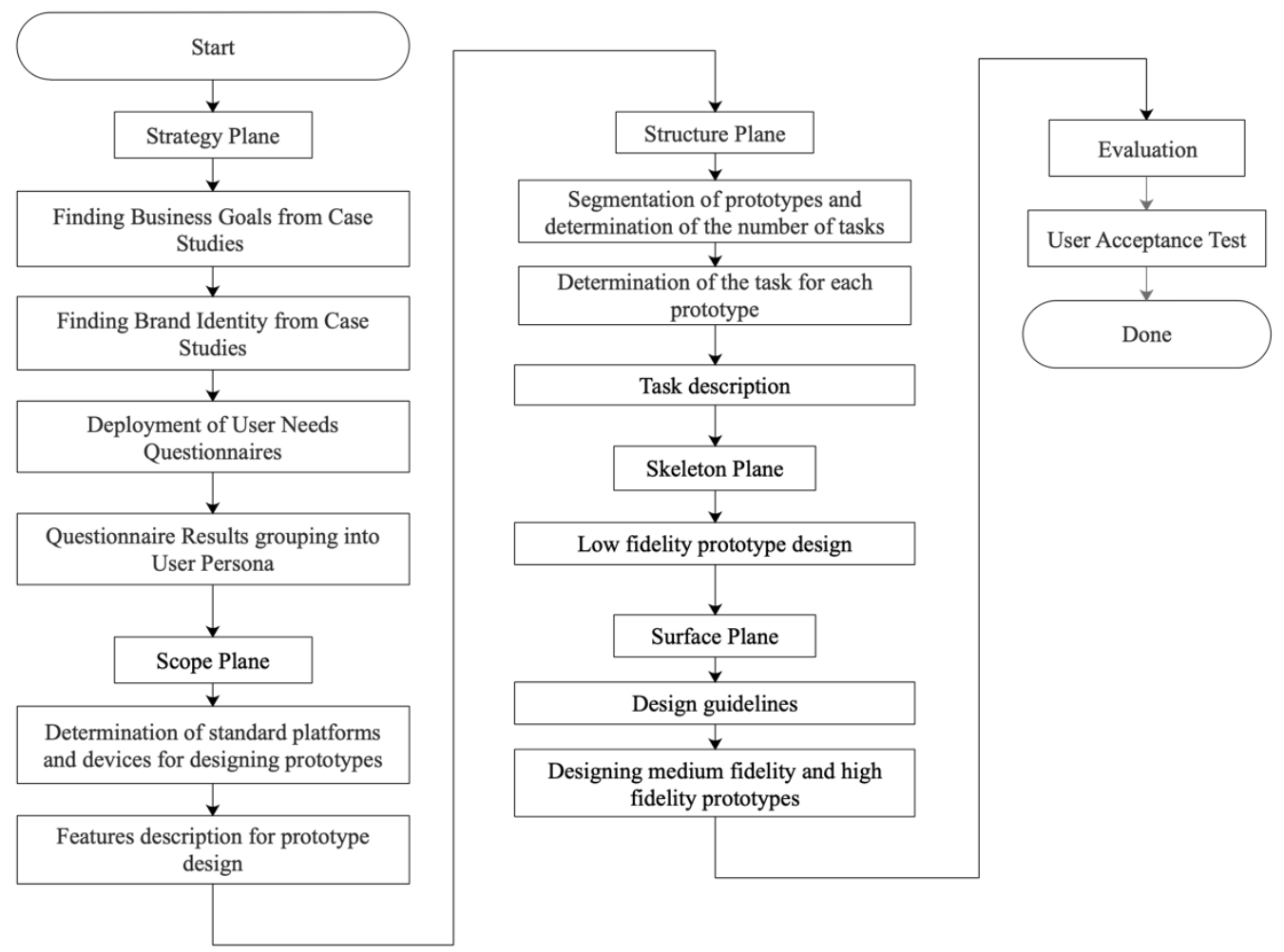

Figure 1. Research Flow

Figure 1 is a research flow starting with the Strategy Plane stage, which is to identify the goals of the Bukaloka company and the needs of Bukaloka users. The Scope Plane stage is carried out standardizing platforms, devices and features that can be used in designing prototypes. Task design and task flow explanation are described in the Structure Plane stage. Skeleton Plane design starts from designing a low fidelity prototype level based on the Task flow that has been previously designed at the Structure Plane stage. The Surface Plane stage 
was executed by designing design guidelines for low fidelity prototypes and producing medium fidelity prototypes [5].

The medium fidelity prototype is then developed into a high fidelity prototype by adding interactions based on the prepared task flow. The evaluation stage is carried out by assessing the prototype by respondents who have tried to use the Bukaloka Marketplace Application prototype. The prototype assessment uses the User Acceptance Test Method with a Likert's Summated Rating.

\subsection{Five Planes Stage}

The prototype design was carried out using the Five Planes Method which was implemented in stages starting from the Strategy Plane, Scope Plane, Structure Plane, Skeleton Plane and Visual Plane.

a. Strategy Plane

The Strategy Plane stage aims to identify the objectives of the Bukaloka company as well as the needs of the target Bukaloka users. The stages in the Strategy Plane start from knowing Bukaloka's business objectives, understanding the Bukaloka brand identity, knowing the needs of Bukaloka Users by distributing questionnaires recapitulated in User Persona to be able to see more clearly the needs of Bukaloka Users [7].

\section{b. Scope Plane}

The Scope Plane stage is carried out standardizing platforms, devices and features that can be used in designing prototypes [5]. Standard setting is intended to facilitate development and minimize errors that can occur due to differences in devices and platforms.

c. Structure Plane

Task design and task flow explanation are described in the Structure Plane stage. The number of tasks designed for the Bukaloka Marketplace application prototype is 10 tasks. The designed task is tailored to the prototype features described in the Scope Plane stage [12].

\section{d. Skeleton Plane}

Skeleton Plane design starts from the low fidelity prototype level based on the previously designed Task flow at the Structure Plane stage, where the low fidelity prototype can make it easier to design in the Visual Plane stage [13].

\section{e. Surface Plane}

The Surface Plane stage was executed by designing the design guidelines. The design guidelines that have been designed are then applied to the low fidelity prototype and produce a medium fidelity prototype [7]. The medium fidelity prototype is then developed by designing the interaction according to the Task flow in the Skeleton Plane stage and producing a high fidelity prototype.

\subsection{User Acceptance Test}

User Acceptance Test (UAT) is done by giving an assessment questionnaire to the prototype which is designed to determine the feasibility of the prototype, where the respondent must first complete the entire Task Flow provided.

The questions in the User Acceptance Test form are based on the respondent's experience when using the prototype as a whole as well as their experience in doing each given task. The writing of the task in the form will be adjusted after the task is described in the Structure Plane stage [14].

The level of scores for the User Acceptance Test is obtained from finding the maximum, minimum, median, quartile scores 1 and quartile scores for each respondent, which is then searched for the total scores for all respondents with all conditions, after which the interpretation of the intervals of the total scores will be seen. 


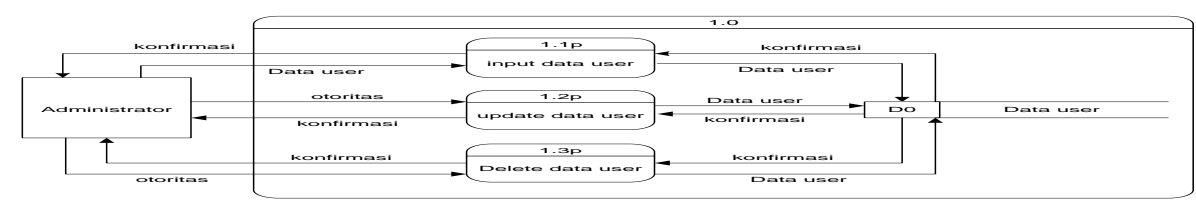

Figure 2. Interval Levels of User Acceptance Test Test Scores

Figure 2 is the level interval for the User Acceptance Test test score, where the prototype is considered not good if the score is between 1 and 2. The prototype is considered neutral if the score is between 2 and 3. The prototype is considered good if the score is between 3 and 4 , and is rated very good when the score is between 4 and 5 .

\section{Literature Study}

The literature used as a research reference is described in a literature review. Sources of research literature are obtained from books, the internet, and journals. The literature review which is used as the basis of research is a study of user experience, Five Planes and user acceptance tests.

\subsection{User Experience}

User Experience (UX) refers to the qualities associated with the user's feelings and emotions [15]. User experience is the perception and response related to user interaction with a system or product [16]. User Experience research focuses on new approaches to designing interactive products that accommodate the quality of experience in using a product [17].

\subsection{Five Planes Method}

The Five Planes method presents a conceptual model for User Experience design. This model simplifies the user experience into five interdependent areas to help design the decision phase and design the overall user experience starting from the Strategy Plane, Scope Plane, Structure Plane, Skeleton Plane and Surface Plane.

The user experience is built from the ground up. The issues to be considered at the lowest level are quite abstract, for example product strategy. With each step to the top, design decisions become more and more concrete. Each stage depends on the decisions made at the stage below it [5].

\subsection{User Acceptance Test Method}

The User Acceptance Test (UAT) method is defined as a type of test performed by research respondents to assess or validate a system in accordance with agreed requirements. This test is carried out at the evaluation stage before it is declared feasible for application development [18].

\section{Result and Discussion}

The results and discussion section displays the results of designing the Bukaloka Marketplace Application prototype as well as the evaluation results using the User Acceptance Test Method.

\subsection{Results of Prototype Design with the Five Planes Method}

The results of designing a prototype using the Five Planes Method show how prototype design occurs in each of the Five Planes stages. The Five Planes stages discussed start from the Strategy Plane, Scope Plane, Structure Plane, Skeleton Plane to Surface Plane stages.

a. Strategy Plane

The first stage in the Strategy Plane is to identify the focus and business objectives of the Bukaloka company by conducting direct interviews with the CEO of Bukaloka. Bukaloka's business model can be seen in Table 1 . 
Table 1. Bukaloka Business Model

\begin{tabular}{cc}
\hline Category & Description \\
\hline Target user & Travel enthusiast (20-35 years old) \\
\hline User demographics & Tourists visiting Indonesia, and local Indonesian residents \\
\hline Service type & $\begin{array}{c}\text { Provider of e-vouchers (culinary, tourist activities, domestic } \\
\text { tours, vehicle rental, relaxation and beauty, souvenirs and } \\
\text { attractions and shows). }\end{array}$ \\
\hline
\end{tabular}

Bukaloka chose navy as a visual brand identity, because it symbolizes a sense of responsibility. Bukaloka establishes a company concept that seems open, friendly, and fun to Bukaloka marketplace customers.

The needs of Bukaloka users were obtained by distributing questionnaires to 10 Bukaloka customers before changing business focus and 10 potential customers who were filtered according to the results of identifying Bukaloka's business focus and objectives. The results of the questionnaire are represented in the form of a persona representing all respondents [19]. The use of personas aims to make it easier to see the variation of respondents based on background, problems, goals and motivations in using the e-voucher provider application.

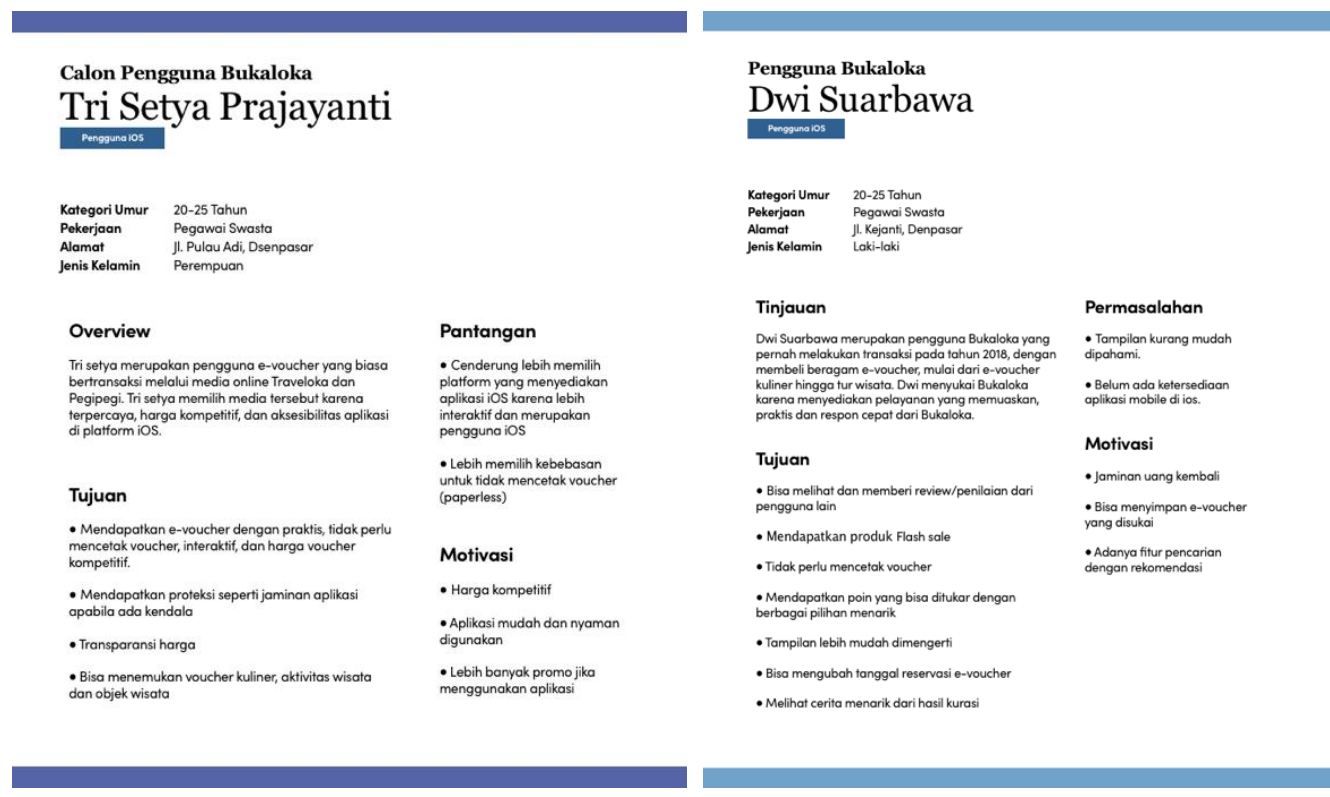

Figure 3. User Persona of Prospective Users and Users of the Bukaloka Marketplace

Figure 3 is the persona of Prospective Users and Users of the Bukaloka Marketplace. Persona of the Bukaloka Marketplace User Candidate takes the names of the Bukaloka User Candidate respondent named Tri Setya. User Persona Bukaloka Marketplace takes one of the names of Bukaloka user respondents named Dwi Suarbawa. Persona is created after analyzing the results of the questionnaire and then accommodating it into a persona that represents Prospective Users and Users of the Bukaloka Marketplace.

\section{b. Scope Plane}

The feature design is carried out at the Scope Plane stage based on the User Persona summary. User persona in the Strategy Plane stage is used to describe the features that will be implemented in the final prototype. 
Table 2. Bukaloka Business Model

\begin{tabular}{cc}
\hline No. & Bukaloka Marketplace Application Features \\
\hline 1 & Search \\
\hline 2 & Filter and Sorting \\
\hline 3 & View E-voucher details \\
\hline 4 & E-voucher Order \\
\hline 5 & E-voucher Payment \\
\hline 6 & Add Reviews \& Rating \\
\hline 7 & Traveller's Story \\
\hline 8 & Favorite \\
\hline 9 & Add to cart \\
\hline 10 & View review \\
\hline 11 & Swipe to redeem \\
\hline 12 & Inbox \\
\hline 13 & Points \\
\hline 15 & Points Exchange \\
\hline 16 & Booking \\
\hline
\end{tabular}

The main features in the Bukaloka marketplace prototype consist of searching with recommendations, viewing e-voucher details, ordering e-vouchers, paying e-vouchers, providing reviews and ratings, user experience stories curated by Bukaloka, storing favorite e-vouchers, add to cart, view reviews, swipe to redeem, inbox, points, redeem points, bookings, and set up accounts.

\section{c. Structure Plane}

The features described at the Scope Plane stage are used as a reference in designing the prototype testing task flow. The description of the 10 design tasks for the Bukaloka Marketplace Application prototype can be seen in Table 3.

Table 3. Bukaloka Marketplace Prototype Task Flow

\begin{tabular}{cll}
\hline No. & \multicolumn{1}{c}{ Task } & \multicolumn{1}{c}{ Task Flow } \\
\hline 1 & $\begin{array}{l}\text { Test the direct purchase } \\
\text { flow without using a cart }\end{array}$ & $\begin{array}{l}\text { Open the culinary menu, find one of the culinary tickets, } \\
\text { then make a purchase directly without adding to cart. }\end{array}$ \\
\hline 2 & $\begin{array}{l}\text { Test the flow of using the } \\
\text { search feature }\end{array}$ & $\begin{array}{l}\text { Open the beauty \& relaxation menu, use the search } \\
\text { feature to find various beauty \& relaxation vouchers } \\
\text { located in Denpasar. }\end{array}$ \\
\hline 3 & $\begin{array}{l}\text { Test the flow of the inbox } \\
\text { feature }\end{array}$ & $\begin{array}{l}\text { Find the inbox feature, then open one of the messages } \\
\text { contained in the inbox. }\end{array}$ \\
\hline 4 & $\begin{array}{l}\text { Test the flow of favorite } \\
\text { features }\end{array}$ & $\begin{array}{l}\text { Open the souvenir menu, then save one of the products } \\
\text { using the save button, then see the saved voucher } \\
\text { located on your account menu. }\end{array}$ \\
\hline 5 & $\begin{array}{l}\text { Test the flow of the points } \\
\text { feature }\end{array}$ & $\begin{array}{l}\text { Open the point redemption menu by touching the } \\
\text { number of points you have, then redeem the points by } \\
\text { selecting one of the available coupons. }\end{array}$ \\
\hline 6 & $\begin{array}{l}\text { Test the voucher exchange } \\
\text { flow }\end{array}$ & $\begin{array}{l}\text { Exchange the culinary vouchers contained in your } \\
\text { booking menu by opening the voucher then swiping to } \\
\text { be able to exchange the voucher. }\end{array}$ \\
\hline 7 & $\begin{array}{l}\text { Test the flow of the filter } \\
\text { feature }\end{array}$ & $\begin{array}{l}\text { Open the culinary menu, then select a location in } \\
\text { popular places, and select the filter feature, then } \\
\text { activate several filters and close the filter feature. }\end{array}$ \\
\hline
\end{tabular}




\begin{tabular}{cll}
\hline 8 & $\begin{array}{l}\text { Test the add to cart feature } \\
\text { flow }\end{array}$ & $\begin{array}{l}\text { Open the culinary menu, then select a culinary product } \\
\text { then make a purchase of } 2 \text { products by pressing the add } \\
\text { to cart feature. }\end{array}$ \\
\hline 9 & Test the rent car flow & $\begin{array}{l}\text { Open the rent car menu, find the availability of the } \\
\text { vehicle according to the available data, then select a car } \\
\text { and the rental car provider vendor, then complete the } \\
\text { payment process. }\end{array}$ \\
\hline 10 & $\begin{array}{l}\text { Test the traveller's story } \\
\text { flow }\end{array}$ & $\begin{array}{l}\text { Find traveler's story in the home menu, then open the } \\
\text { story in Labuan Bajo. }\end{array}$ \\
\hline
\end{tabular}

Table 3 is a description of the Task Flow of the Bukaloka Marketplace prototype. The task flow is used as a reference for designing low fidelity prototypes in the Skeleton Plane stage. The Task Flow is used at the Evaluation stage so that respondents can provide an assessment of the Bukaloka Marketplace Application prototype after completing the entire Task Flow provided.

d. Skeleton Plane

The task flow that has been designed in the Structure Plane stage is used as a reference in designing the content and layout of the low fidelity prototype interface design of Bukaloka.

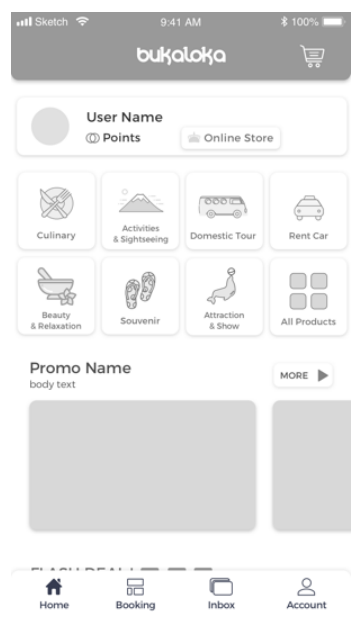

Figure 4. Wireframe Main Menu of Bukaloka Marketplace

Figure 4 is a wireframe (low fidelity prototype) of the main menu of the Bukaloka marketplace. The main menu layout for the Bukaloka marketplace consists of a header containing the cart and the Bukaloka logo, brief information about users, points, shortcuts to owned online shops, Bukaloka service menus, and promotions. The navigation bar of the Bukaloka marketplace application consists of the home, booking, inbox and account menus.

\section{e. $\quad$ Surface Plane}

The Surface Plane stage was executed by designing the design guidelines. The design guidelines that have been designed are then applied to the low fidelity prototype and produce a medium fidelity prototype. The medium fidelity prototype is then developed by designing the interaction according to the Task Flow in the Skeleton Plane stage and producing a high fidelity prototype. 


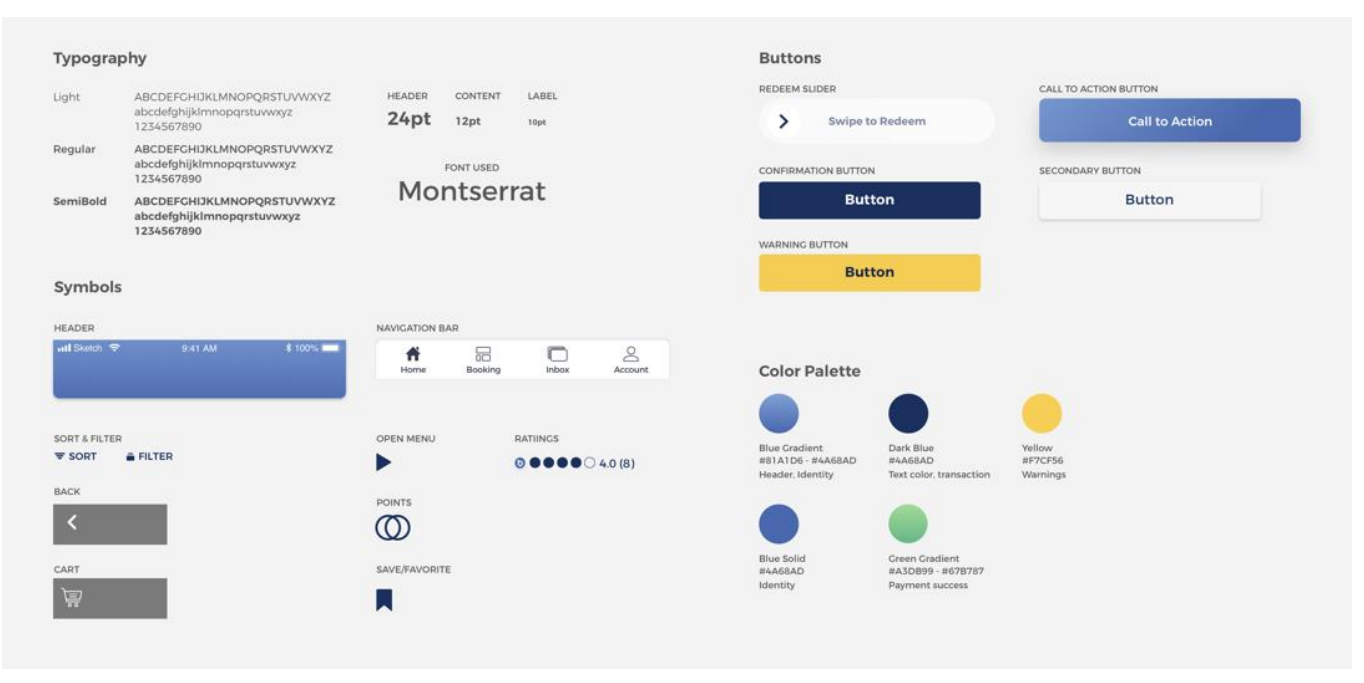

Figure 5. Design Guidelines Prototipe Marketplace Bukaloka

Design guidelines are used as a reference in designing the medium fidelity prototype. Design guidelines are divided into 4 segments, namely typography, symbols, button choices and color choices.

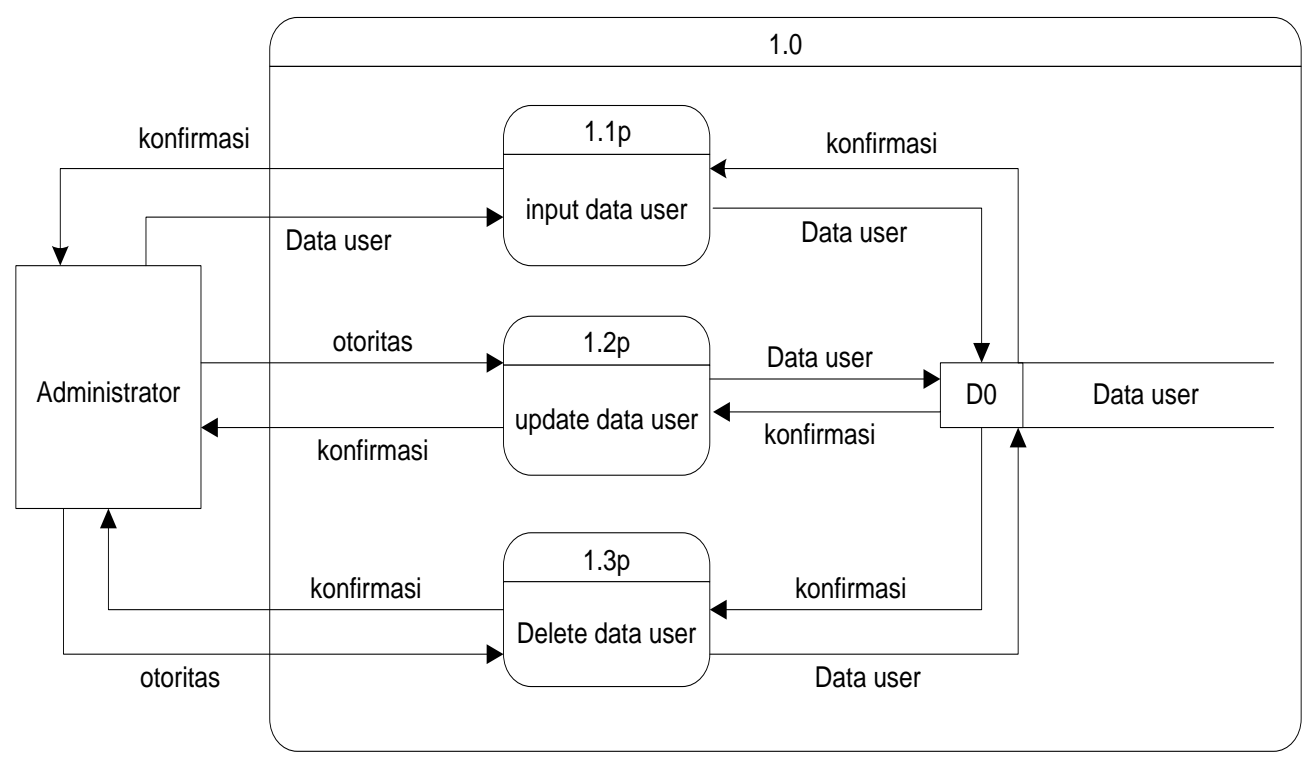

Figure 6. High Fidelity Prototype Design Results

Figure 6 is one of the results of micro-interaction design on the e-voucher exchange process. The e-voucher exchange process will be executed when the Swipe to Redeem button is shifted from the left side to the right side. The prototype will complete the e-voucher exchange verification series until the exchange is complete.

\subsection{Result of Prototype Evaluation with User Acceptance Test}

The results of the User Acceptance Test form that have been distributed to respondents who have completed the Usability Testing are evaluated using the Likert's Summated Rating method. 
Table 4. User Acceptance Test Results for the Bukaloka Marketplace

\begin{tabular}{|c|c|c|c|c|c|c|}
\hline \multirow[b]{2}{*}{ No. } & \multirow[b]{2}{*}{ Questions } & \multicolumn{4}{|c|}{ Respondent's answer } & \multirow[t]{2}{*}{ Total } \\
\hline & & $\begin{array}{l}\text { Very } \\
\text { Good } \\
(4)\end{array}$ & $\begin{array}{c}\text { Good } \\
(3)\end{array}$ & $\begin{array}{c}\text { Neutral } \\
(2)\end{array}$ & $\begin{array}{c}\text { Not } \\
\text { Good } \\
(1)\end{array}$ & \\
\hline 1 & $\begin{array}{l}\text { What do you think about the general } \\
\text { appearance of the application? }\end{array}$ & 14 & 6 & 0 & 0 & 20 \\
\hline 2 & $\begin{array}{l}\text { How do you look and interact when } \\
\text { ordering culinary vouchers? }\end{array}$ & 10 & 10 & 0 & 0 & 20 \\
\hline 3 & $\begin{array}{l}\text { How do you look and interact when } \\
\text { searching for beauty \& relaxation } \\
\text { vouchers in Denpasar? }\end{array}$ & 9 & 11 & 0 & 0 & 20 \\
\hline 4 & $\begin{array}{l}\text { How is the appearance and interaction } \\
\text { when opening a message in the inbox? }\end{array}$ & 12 & 7 & 1 & 0 & 20 \\
\hline 5 & $\begin{array}{l}\text { How do you look and interact when you } \\
\text { go through the process of searching for, } \\
\text { and storing one of the souvenirs and then } \\
\text { seeing the stored item? }\end{array}$ & 4 & 7 & 4 & 5 & 20 \\
\hline 6 & $\begin{array}{l}\text { How do you look and interact when } \\
\text { exchanging Bukaloka points? }\end{array}$ & 8 & 11 & 1 & 0 & 20 \\
\hline 7 & $\begin{array}{l}\text { How do you look and interact when } \\
\text { exchanging vouchers? }\end{array}$ & 13 & 7 & 0 & 0 & 20 \\
\hline 8 & $\begin{array}{l}\text { How was the appearance and interaction } \\
\text { when trying the filter feature? }\end{array}$ & 6 & 13 & 1 & 0 & 20 \\
\hline 9 & $\begin{array}{l}\text { How is the appearance and interaction } \\
\text { when purchasing } 2 \text { vouchers at once } \\
\text { using the add to cart feature? }\end{array}$ & 12 & 8 & 0 & 0 & 20 \\
\hline 10 & $\begin{array}{l}\text { How do you look and interact when } \\
\text { booking a rental car? }\end{array}$ & 13 & 7 & 0 & 0 & 20 \\
\hline 11 & $\begin{array}{l}\text { How do you look and interact when you } \\
\text { find interesting stories from Labuan Bajo? }\end{array}$ & 4 & 8 & 8 & 0 & 20 \\
\hline 12 & $\begin{array}{l}\text { Will this application make it easier for } \\
\text { people to order vouchers online? }\end{array}$ & 15 & 5 & 0 & 0 & 20 \\
\hline & Sum & 120 & 100 & 15 & 5 & 240 \\
\hline & Total Score & 480 & 300 & 30 & 5 & \\
\hline
\end{tabular}

Table 4 is a summary of the results of the User Acceptance Test form for user respondents and potential users of the Bukaloka marketplace. The total score for the not good, neutral, good and very good categories is 815 . The scoring category is obtained from assigning the maximum, minimum, median, quartile 1 and quartile 2 scores as a range of scores. The maximum total score used for the highest score range is obtained if all respondents give a very good score, namely 960 . The minimum score if all respondents give a bad score is 240 . The median score which is the middle value between the maximum score and the minimum score is 600 . Score quartile 1 the median between the minimum and the median scores is 480 . The 2 quartile score, which is the midpoint between the maximum and median scores, is 720 .

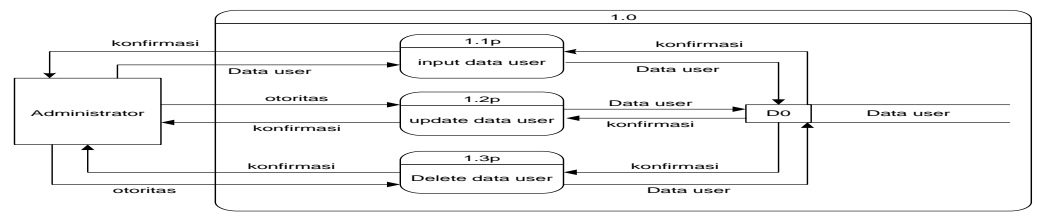

Figure 7. Interpretation of User Acceptance Test Score Levels

Figure 7 is an interpretation of the level of the User Acceptance Test score obtained. The score for the User Acceptance Test of 815 is in the 2 nd quartile of 720 with a maximum 
score of 960 which indicates that the assessment of the prototype falls into a very good category range.

\subsection{Analysis of Test Results}

Based on the results of the assessment of the Bukaloka Marketplace Application prototype, respondents who gave sufficient and poor ratings to the Bukaloka Marketplace Application prototype had a response to the assessment given. An explanation of the respondent's response to the adequate and bad category ratings can be seen in Table 5 .

Table 5. Respondents' Responses to the Assessment Results

\begin{tabular}{|c|c|c|}
\hline No. & Questions & Response \\
\hline 4 & $\begin{array}{l}\text { How is the appearance and interaction } \\
\text { when opening a message in the inbox? }\end{array}$ & $\begin{array}{l}\text { It needs increased visibility to indicate } \\
\text { unopened messages. }\end{array}$ \\
\hline 5 & $\begin{array}{l}\text { How do you look and interact when you go } \\
\text { through the process of searching for, and } \\
\text { storing one of the souvenirs and then } \\
\text { seeing the stored item? }\end{array}$ & Having trouble finding the save button. \\
\hline 6 & $\begin{array}{l}\text { How do you look and interact when } \\
\text { exchanging Bukaloka points? }\end{array}$ & $\begin{array}{l}\text { The initial number of points is } 1040 \text {, } \\
\text { then exchanges } 1000 \text { points but the } \\
\text { number of points after redemption } \\
\text { remains } 1040 \text {. }\end{array}$ \\
\hline 8 & $\begin{array}{l}\text { How was the appearance and interaction } \\
\text { when trying the filter feature? }\end{array}$ & Difficulty closing the filter freature. \\
\hline 11 & $\begin{array}{l}\text { How do you look and interact when you find } \\
\text { interesting stories from Labuan Bajo? }\end{array}$ & $\begin{array}{l}\text { The font used is unusual, a little } \\
\text { difficult to read at first. }\end{array}$ \\
\hline
\end{tabular}

Table 5 is a description of the responses of respondents who gave sufficient and bad scores to several points in testing the Bukaloka Marketplace Application prototype. Responses from respondents are used as a reference for recommendations for improvement of the Bukaloka Marketplace Application prototype.

\subsection{Recommendations and Improvement Results}

Based on respondents' responses to the Bukaloka Marketplace Application prototype, the results of recommendations for prototype improvements can be seen in Table 6 .

Table 6. Prototype Improvement Recommendations

\begin{tabular}{cll}
\hline No. & \multicolumn{1}{c}{ Response } & \multicolumn{1}{c}{ Recommended improvements } \\
\hline 1 & $\begin{array}{l}\text { It needs increased visibility to indicate } \\
\text { unopened messages. }\end{array}$ & $\begin{array}{l}\text { Provides a marker of comparison to unread } \\
\text { and read messages. }\end{array}$ \\
\hline 2 & $\begin{array}{l}\text { Having trouble finding the save } \\
\text { button. }\end{array}$ & $\begin{array}{l}\text { Provides tips that can make it easier for users } \\
\text { to find the save button. }\end{array}$ \\
\hline 3 & $\begin{array}{l}\text { The initial number of points is 1040, } \\
\text { then exchanges 1000 points but the } \\
\text { number of points after redemption } \\
\text { remains 1040. }\end{array}$ & $\begin{array}{l}\text { Show the points that have been deducted } \\
\text { from the point redemption. }\end{array}$ \\
\hline 4 & Difficulty closing the filter freature. & Add button to close filter. \\
\hline 5 & $\begin{array}{l}\text { The font used is unusual, a little } \\
\text { difficult to read at first. }\end{array}$ & $\begin{array}{l}\text { Use a more familiar font for the words } \\
\text { "Labuan Bajo", so it's easy to read. }\end{array}$ \\
\hline
\end{tabular}

Table 6 is a description of the recommendations for improving the Bukaloka Marketplace Application prototype to the respondents' responses. Recommended improvements are used to improve the Bukaloka Marketplace Application prototype. 

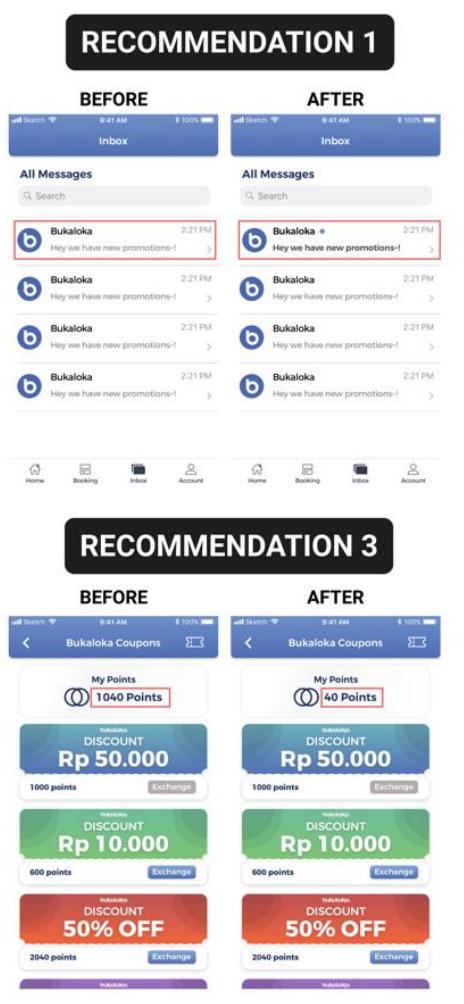

\section{RECOMMENDATION 2}

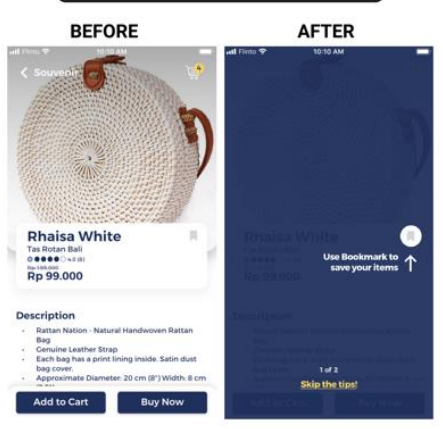

RECOMMENDATION 4

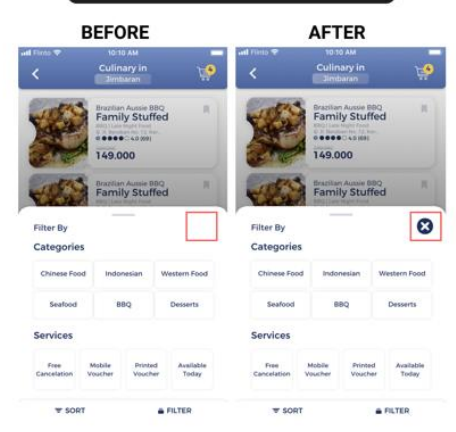

RECOMMENDATION 4

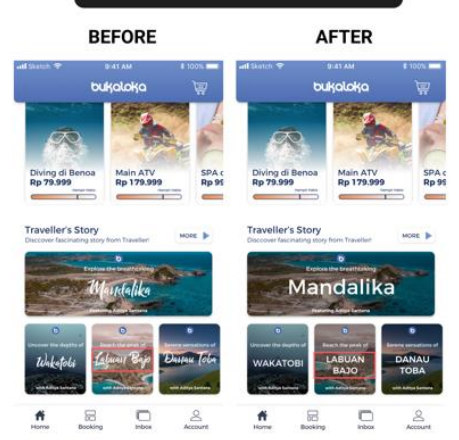

Figure 8. Results of Improvement Recommendations

Figure 8 is the result of the prototype repair based on 5 recommendations for improvement from the respondent. The improvement for recommendation 1 is the provision of comparative markers for unread and read messages. The improved prototype has a blue dot and a thicker font to indicate unread messages. The fix for recommendation 2 is the provision of tips that can make it easier for users to find the save button. The fix for recommendation 3 is the appearance of points that have been reduced after the point redemption is made. The fix for recommendation 4 is adding a button to close the filter function. The improvement for recommendation 5 is the use of a more familiar font for the words "Labuan Bajo", so that it is easy to read.

\section{Conclusion}

The design of the prototype was carried out using the Five Planes method with 5 consecutive stages, namely the Strategy Plane, Scope Plane, Structure Plane, Skeleton Plane and Surface Plane stages. The Strategy Plane stage is to find out what the goals of the Bukaloka company are and to find out the needs of the target users of Bukaloka. The Scope Plane stage is the determination of the platform, devices and features used in designing the prototype. The Structure Plane stage is a task design and an explanation of the task flow using the Sequential Structure method. The Skeleton Plane stage is designing a low fidelity prototype based on the task flow in the Structure Plane stage. The Surface Plane stage is designing a design guideline, a prototype of medium fidelity and high fidelity. The high fidelity prototype functionality has run well in accordance with the features and task flow that has been designed. The results of the User Acceptance Test on the Bukaloka Marketplace Application prototype showed that the prototype was in the very good category with a score of 815 . Responses from respondents to the prototype were used as a reference for recommendations for improvement. Recommended improvements are used for improvements to the designed prototype. 


\section{References}

[1] H. Supriyono, E. Sudarmilah, U. Fadlilah, E. T. Rahayu, and A. Purwohartono, "Rancang bangun media pembelajaran bahasa dan huruf jawa berbasis adobe flash cs6," 2015.

[2] P. D. W. Anggoro, "Design of Web Virtual Reality for Job Interview Preparation Simulation," Lontar Komput. J. IIm. Teknol. Inf., vol. 11, no. 3, pp. 132-143, 2020.

[3] P. L. Dwyer, P. P. Forsyth, and W. Dwyer, Tourism Economics and Policy. Channel View Publications, 2020.

[4] P. T. Fajarini, N. K. A. Wirdiani, and I. P. A. Dharmaadi, "Evaluasi Portal Berita Online pada Aspek Usability Menggunakan Heurtistic Evaluation dan Think Aloud," J. Teknol. Inf. dan IImu Komput., vol. 7, no. 5, pp. 905-910, 2020.

[5] E. Park, "Motivations for customer revisit behavior in online review comments: Analyzing the role of user experience using big data approaches," J. Retail. Consum. Serv., vol. 51, pp. 14-18, 2019.

[6] A. J. Priana, H. Tolle, I. Aknuranda, and E. Arisetijono, "Design of Mobile Finger Communications Board for Stroke Patient Using The Five Planes of User Experience," J. Inf. Technol. Comput. Sci., vol. 2, no. 2, 2018.

[7] A. I. G. Prakasa and F. Ardiansyah, "Perancangan User Experience Aplikasi Marketplace Paket Wisata Indonesia untuk Wisatawan Lokal," J. IImu Komput. dan AgriInformatika, vol. 5, no. 1, pp. 51-60, 2018.

[8] A. Santana, "Wawancara Market Validation November," 2018.

[9] R. H. D. Putra, H. Sujaini, and N. Safriadi, "Penerapan Metode Haversine Formula Pada SistemInformasi Geografis Pengukuran Luas Tanah," JUSTIN (Jurnal Sist. dan Teknol. Informasi), vol. 4, no. 1, pp. 157-162, 2015.

[10] M. E. Brown and D. L. Hocutt, "Learning to use, useful for learning: a usability study of Google apps for education," J. Usability Stud., vol. 10, no. 4, pp. 160-181, 2015.

[11] C. M. Barnum, Usability testing essentials: ready, set... test! Morgan Kaufmann, 2020.

[12] A. Henry, Platform and Collective Intelligence: Digital Ecosystem of Organizations. John Wiley \& Sons, 2021.

[13] S. N. Sathiyamurthy, "Measuring Haptic Experience: Evidence for the HX model through scale development." University of Waterloo, 2020.

[14] L. Rivero and T. Conte, "A systematic mapping study on research contributions on UX evaluation technologies," in Proceedings of the XVI Brazilian Symposium on Human Factors in Computing Systems, 2017, p. 5.

[15] N. L. P. A. Wedayanti, N. K. A. Wirdiani, and I. K. A. Purnawan, "Evaluasi Aspek Usability pada Aplikasi Simalu Menggunakan Metode Usability Testing," J. IIm. Merpati (Menara Penelit. Akad. Teknol. Informasi), pp. 113-124, 2019.

[16] L. P. Wanti, H. F. M. Insan, and N. W. A. Prasetya, "End User Satisfaction for Location Health Service Application with Analysis of Task Technology Fit," Lontar Komput. J. IIm. Teknol. Informasi; Vol 11 No 2 Vol. 11, No. 2 August 2020, 2020.

[17] N. Islam, "User-centered evaluation of the CERO simulation tool." 2020.

[18] R. Hartson and P. S. Pyla, The UX book: Agile UX design for a quality user experience. Morgan Kaufmann, 2018.

[19] V. A. Lestari, I. Aknuranda, F. \%J J. of T. Ramdani Electronic, and C. Engineering, "Usability Evaluation of E-Government using ISO 9241 and Fuzzy Tsukamoto Approach," vol. 9, no. 2-8, pp. 153-157, 2017. 